


\section{DISCLAIMER}

This report was prepared as an account of work sponsored by an agency of the United States Government. Neither the United States Government nor any agency Thereof, nor any of their employees, makes any warranty, express or implied, or assumes any legal liability or responsibility for the accuracy, completeness, or usefulness of any information, apparatus, product, or process disclosed, or represents that its use would not infringe privately owned rights. Reference herein to any specific commercial product, process, or service by trade name, trademark, manufacturer, or otherwise does not necessarily constitute or imply its endorsement, recommendation, or favoring by the United States Government or any agency thereof. The views and opinions of authors expressed herein do not necessarily state or reflect those of the United States Government or any agency thereof. 


\section{DISCLAIMER}

Portions of this document may be illegible in electronic image products. Images are produced from the best available original document. 
This book was prepared as an account of work sponsored by an agency of the United States Government. Neither the United States Government nor any agency thereof, nor any of their employees, makes any warranty, express or implied, or assumes any legal liability or responsibility for the accuracy, completeness, or usefulness of any information, apparatus, product, or process disclosed, or represents that its use would not infringe privately owned rights. Reference herein to any specific commercial product, process, or service by trade name, trademark, manufacturer, or otherwise, does not necessarily constitute or imply its endorsement, recommendation, or favoring by the United States Government or any agency thereof. The views and opinions of authors expressed herein do not necessarily state or reflect those of the United States Government or any agency thereof. 
Submitted to the Proceedings of the Second

Symposium on the Cerro Prieto Geothermal Field,

Baja California, Mexico, October 17-19, 1979

INTERSECTING FAULTS AND SANDSTONE STRATIGRAPHY AT THE

CERRO PRIETO GEOTHERMAL FIELD

Stephen Vonder Haar and J. H. Howard

Lawrence Berkeley Laboratory

University of California

Berkeley, California 94720

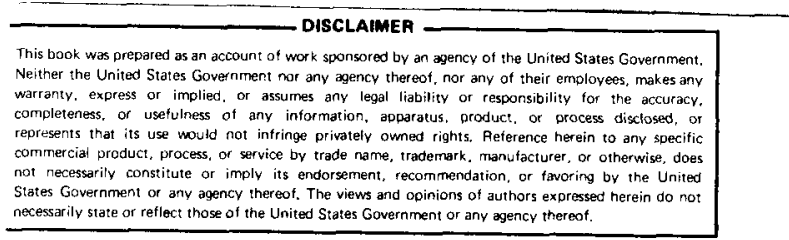

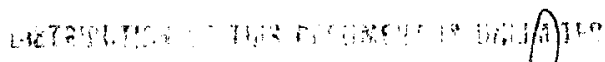




\title{
INTERSECTING FAULTS AND SANDSTONE STRATIGRAPHY AT THE CERRO PRIETO GEOTHERMAL FIELI
}

\author{
Stephen Vonder Haar and J. H. Howard \\ Lawrence Berkeley la boratory \\ Unfversity of California \\ Berkeley, California 94720
}

\section{ABSTRACT}

The northwest-southeast trending Cerro Prieto fault is part of a major regional lineament that extends into Sonora and has characteristics of both a wrench fault and an oceanic transform fault. It apparently penetrates deep into the basement and crustal rocks in the area and serves as a condult for both large and rapid heat flow. Near well M-103, where the Michaacín fault zone obliquely intersects a shorter northeast-southwest trending fault, large ctrculation losses during drilling Indicate greater permeabllity and hence increased natural convective fluid flow. In the southern portion of the field, there 18 a shear fault zone in the vicintty of wells $M-48$, $M-91$, and $M-101$. Temperature contour maps suggest that this shear zone aids in rapidly distributing geothermal flutd awa from the Cerro Prieto fault zone, thus enhancing recharge.

We have studied the distribution of lithologies and temperature within the fleld by comparing data from well cuttings, cores, well logs, and geochemical analyses. Across the earliest developed portion of the fleld, in particular along a $1.25-\mathrm{km}$ northeast-southwest section from well $M-9$ to $M-10$, interesting correlations emerge that indicate a relationship among 11 thology, microfracturing, and temperature distribution. In the upper portion of Reservoir A of this stratigraphic section, between 1200 and $1400 \mathrm{~m}$, the percentage of sandstones ranges from 20 to 55. Temperatures are $225^{\circ}$ to $275^{\circ} \mathrm{C}$ based on well logs, calcite 1sotope maxima, and $\mathrm{Na}-\mathrm{K}-\mathrm{Ca}$ Indices. Our study shows that an isothermal high in this vicinity corresponds to the lowest total percentage of sandstones. Scanning electron microphotographs of well cores and cuttings from sandstone and shale units reveal clogging, mineral dissolution, and mineral prectp1tation along microfractures. Our working hypothesis is that these sandy shale and siltstone facies are most amenable to increased microfracturing and, in turn, such microfracturing allows for higher temperature fluid to rise to shallower depths in the reservolr.

Ongolng research is almed at achieving a coherent geological model that illustrates reservolr capacity, and at understanding fluid flow along for faults, lateral distribution through fault shear zones, and varlable movement within deltaic clastics that have in part been microfractured.

\section{INTRODUCTION}

Geological evolution of the Cerro prieto region ( $F 1 \mathrm{~g} .1$ ) has been a complex blend of rifting, rapld deltalc sedimentation, and largescale strike-slip faulting. To understand geothermal fields in this region, it is important to be familiar with the fault intersections and with the effects of tectonism and ter-rock interactions on initial sandstone porosity and permeability. In this paper, we first explore analogs for the pattern of faulting at Cerro Prieto and then focus on secondary porosity and permeability in the producting hortzons.

\section{SALTON TROUGH FAULTING}

In Figure 2, a detafled compilation of faulting fllustrates a number of fault intersections. These data were complled from more than 100 published and unpublished articles with many of the spectfic key references shown in Figure 3. The Salton Sea area has a distinct northeastsouthwest serles of faults, each approximately

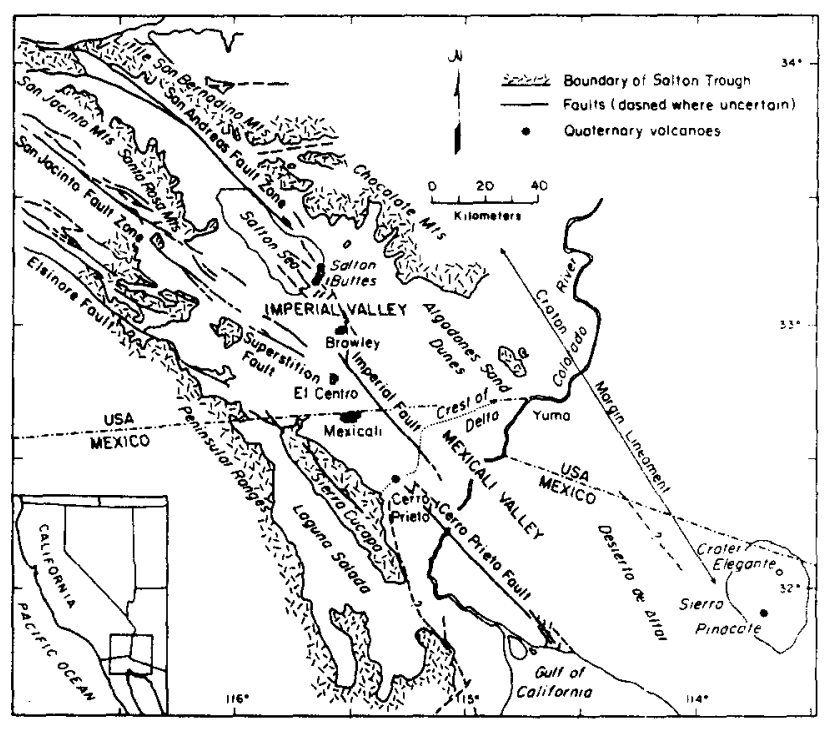

XBL BO1-6716

Figure 1. Location map of the reglonal geology of the Cerro Prieto geothermal field. 
SALTON TROUGH FAULTING

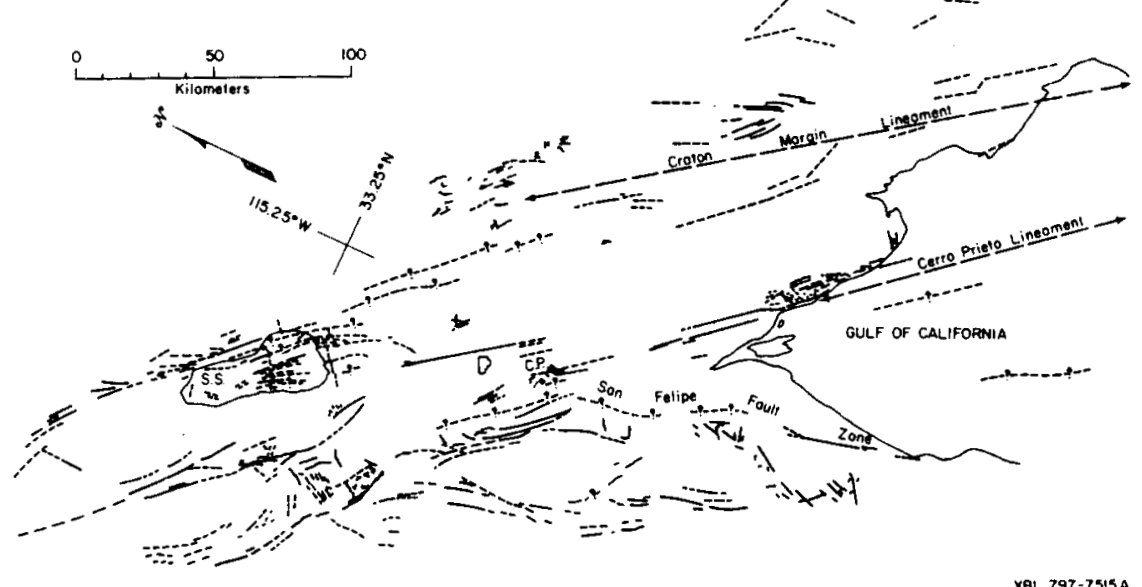

Figure 2. Salton Trough faults indicating zone of cross faulting and the mafor northwestsoutheast hybrid transform faults.

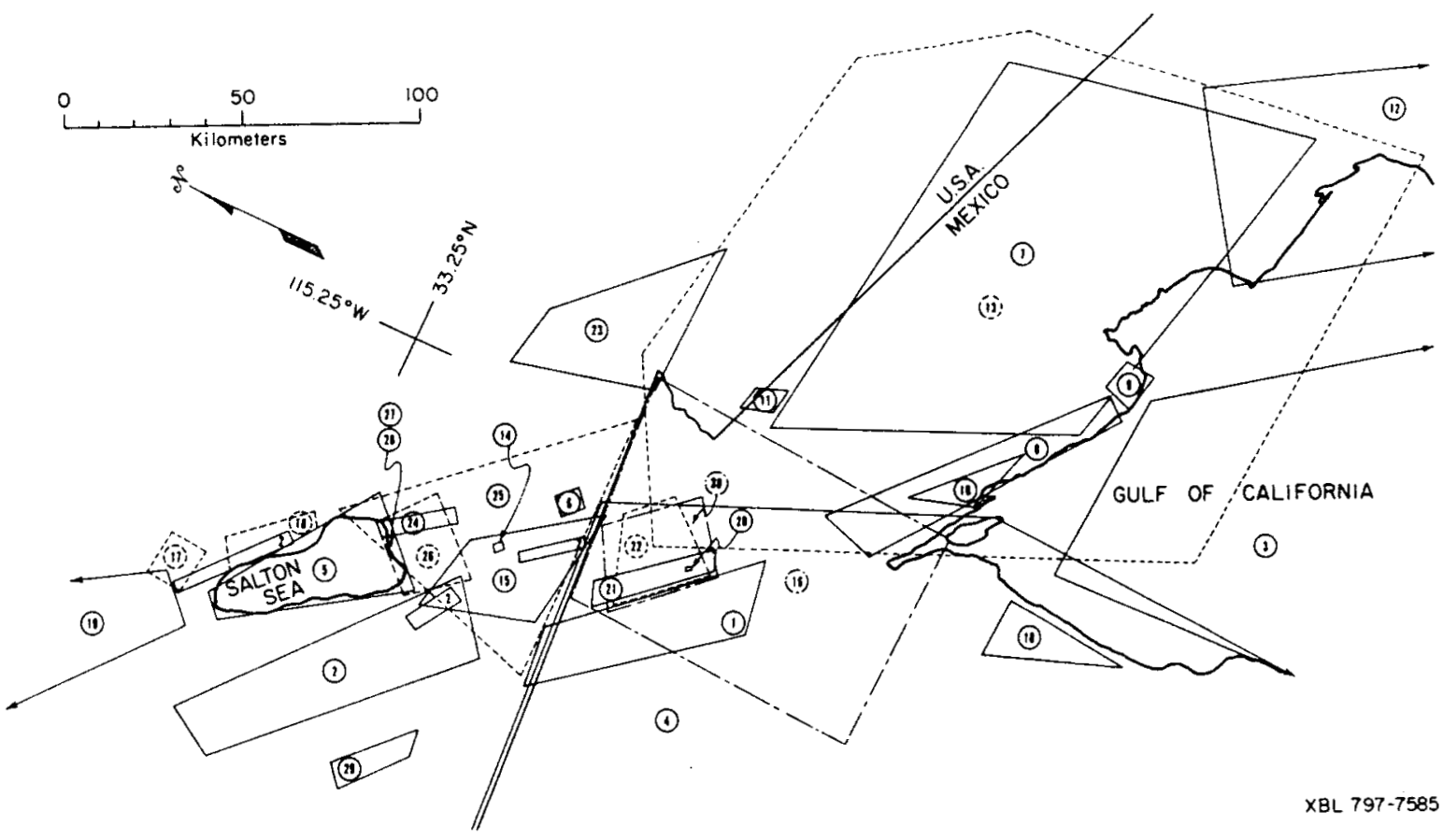

Figure 3. Key reference map to articles on Salton Trough faulting. KEY: (1) Barnard, 1968; (2) USGS, 1972; (3) Henyey and Blschoff, 1973; (4) Gast1l et al., 1975; (5) Meldav and Rex, 1970; (6) Howard et a1., 1979; (7) Donnelly, 1974; (8) Ortlieb, 1978; (9) Vonder Haar and Gorsline, 1977; (10) Vonder Haar and Gorsline, 1975; (11) Puente C. and Vonder Haar, 1980; (12) Gast11 and Grumenscher, 1977; (13) Sumner, 1972; (14) Sharp, 1976; Johnson and Hadley, 1976;

(15) Goulty and Golman, 1978; (16) De la Fuente and Sumner, 1974; (17) Sylvester and Smith, 1976; (18) Babcock, 1974; (19) Proctor, 1968; (20) Noble et al., 1977; Razo, 1976; Alonso, 1966; Reed, 1976; Mercado, 1976; Vonder Haar and Puente C., 1979; Prian C., 1979; Corwin et al., 1978; and Alonso E. et al., 1979; (21) Puente C., and de la Peña L., 1979; (22) Soto-P., 1975; (23) Crowe, 1978; (24) Kasameyer, 1976; Kasameyer et a1., 1978; (25) Lofgren, 1979; (26) Meidav et al., 1976; (27) Twehey, 1977; (28) Chan and Tewhey, 1977; (29) Todd and Hoggatt, 1976; (30) Albores et al., 1979. 
$3 \mathrm{~km}$ long between the Banning/Mission Creek strikeslip fault (part of the San Andreas system) and the northern end of the Brawley/Imperial strikeslip fault (Fig. 4; also Meidav and Howard, 1979).

Simflar northeast-southwest trending across faults at the Cerro Prieto fleld (Fig. 5) have been confirmed by recent studies (Vonder Haar and Puente C., 1979; Puente C. and de la Peña L., 1979). The northwest-southeast trending Cerro Prieto fault and a parallel fault segment, the Michoacán fault, are part of a major regional ineament that reaches into Sonora (Gastil and Krummenacher, 1977) and has characteristics of both a wrench fault zone and an oceanic transform fault (see Vonder Haar and Puente C., 1979). This major regional lineament is believed to penetrate deep into the crustal and basement rocks, which range from $7 \mathrm{~km}$ thick in the northern Gulf of California (Phillips, 1964) to as great as $20 \mathrm{~km}$ at the Mexican/Unfted States international boundary (Biehler et al., 1964). This style of faulting, namely a deep penetrating regional fault with down-dropped blocks at fault intersections is important in connection with the occurrence of geothermal resources because they apparently serve

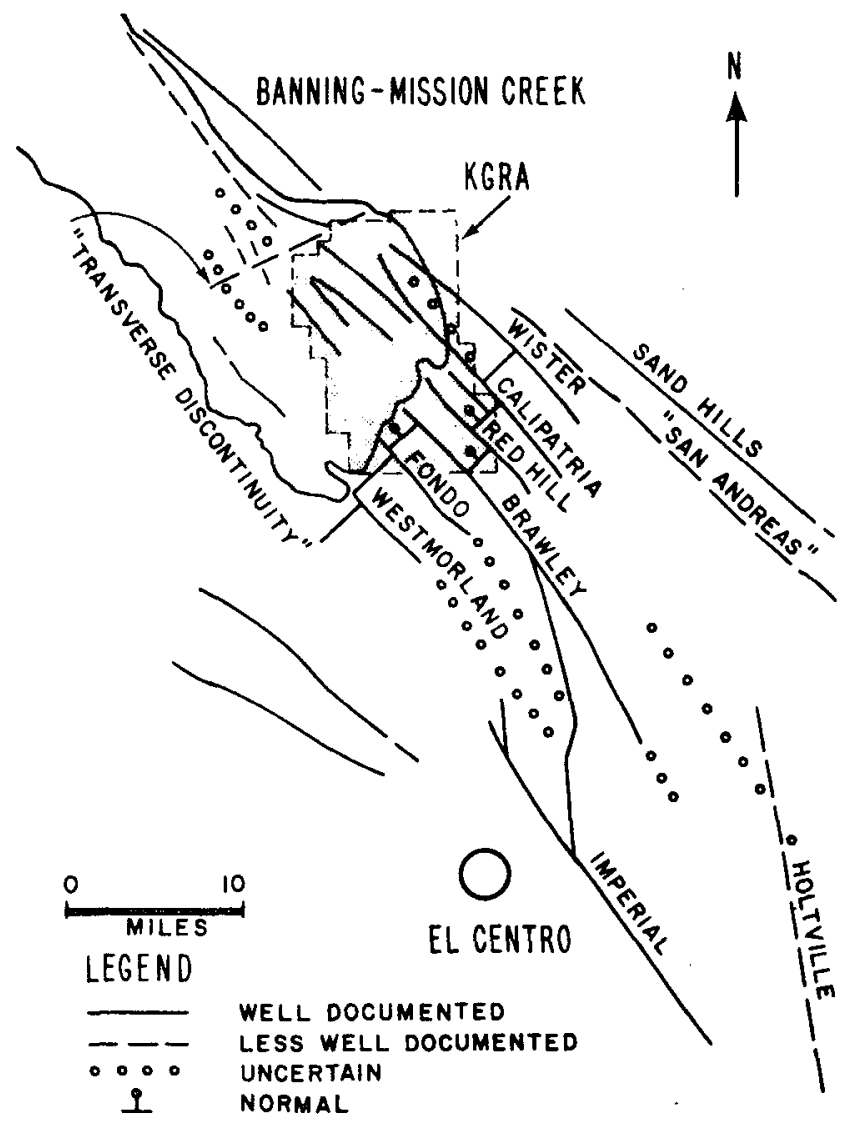

XBL 797-2121A

Figure 4. Structural map of the Salton Sea region based on combined geophysical data.

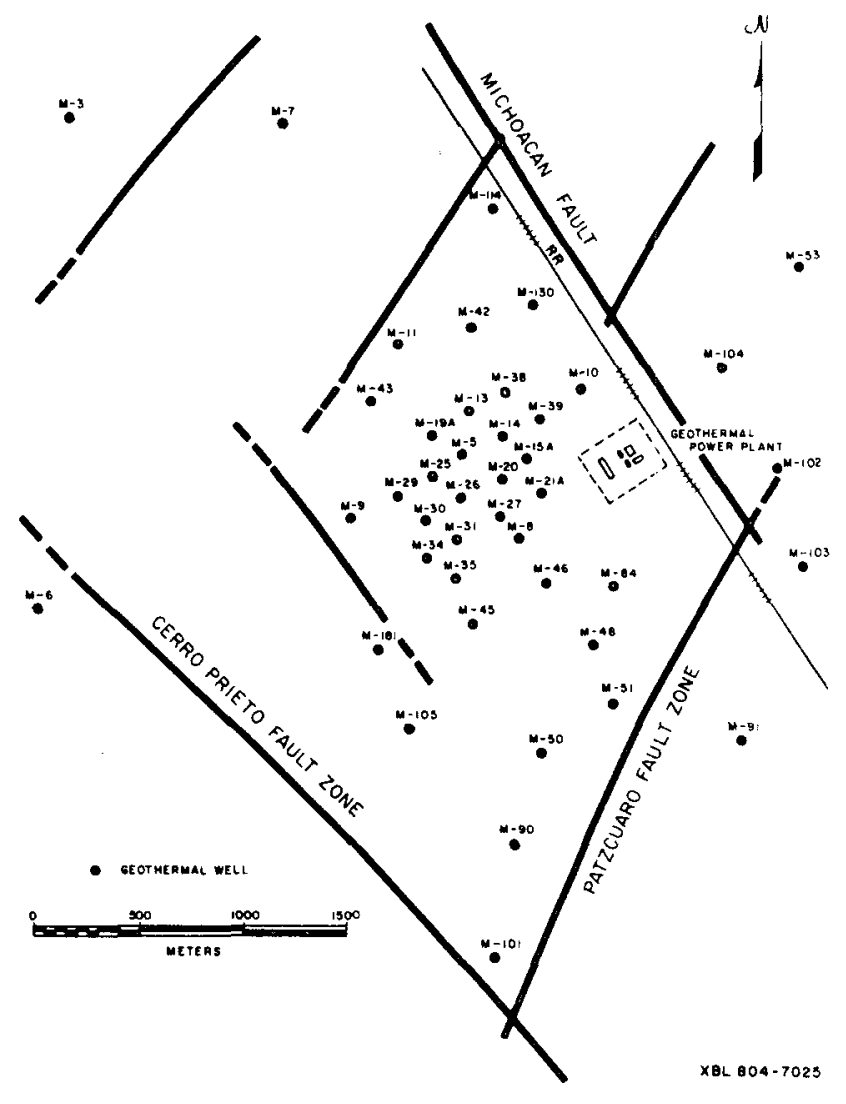

Figure 5. Faults in the vicinity of the Cerro Prieto fleld showing cross-faults and the very productive well $\mathrm{M}-103$.

as conduits for high heat flow. The oblique intersection of the Pátzcuaro fault zone and the Michoacán fault zone are associated with wells having greater permeability and are thus areas presumed to have Increased natural convection. The prolific production of well M-103, large amounts of lost circulation, and the surface manifestations of the Laguna Volcano area southwest of well M-101, support this conclusion. (See the articles by De Boer, 1980; also Valette and Esquer P., 1979, for magnetic and geochemical data related to these fault intersections.)

Another facet of fault intersections is their role in aiding distribution of the geothermal fluids awa from a deep penetrating fault such as the Cerro Prieto fault. Such a fault is belleved to be a linear or perhaps even a discreet point source at a given moment in geologic time (see Delaney and Pollard, 1980). Such a single controlling fault should lead to a fleld that clusters within a few hundred meters of 1 t. However, increased permeability, recharge capacity, and storativity that result from these fault shear zones create geothermal fields on the order of 2 to $10 \mathrm{~km}$ wid ths.

A third area of cross-faulting is (Fig. 2) approxlmately $100 \mathrm{~km}$ southeast of Cerro Prieto, 
where the Cerro Prieto Lineament enters the Gulf of California. These faults have been confirmed by field studies (Ortlieb, 1978). Al though there is an en echelon style to the Cerro Prieto fault zone in this area, flooding frequency and duration data (Vonder Haar and Gorsline, 1979) Indicate that saline surface waters would hamper ground-level geophysical surveys and drilling of shallow wells for heat flux data. Presumably a geothermal resource is present at depth.

St1ll another facet of faulting in the Salton Trough may pertain to the origin of Cerro Prieto volcano and the adjacent geothermal field. Both may be the result of yet another fault intersection, namely the meeting of the basin bounding San Felipe fault zone (Fig. 2) with the Cerro Prieto Lineament.

There are other indications of fault intersection in the Salton Trough/Upper Gulf of California area. Magnetic data suggest reactivation of earlier rifting faults (see de Boer, 1980) and regional gravity data indicate that the Gila Lineament extends into the Salton Trough from Arizona to near the Imperial fault's southernmost end.

\section{TECTONIC ANALOGS TO CERRO PRIETO}

The Dead Sea rift zone, ofl-producing basins in southern California, and the Afar region in Africa, among others, provide stimulating comparisons to the Cerro Prieto region. However, perhaps the most useful models for faulting for Salton Trough geothermal fields come from the detailed observations by deep diving submersibles along transform faults and hydrothermal centers in the FAMOUS area of the mid-Atlantic ridge and in the Gulf of California.

Underwater exploration of transform fault "A" in the FAMOUS area is summarized in a threedimensional block diagram (F1g. 6), on a scale appropriate to the Cerro Prieto field. As shown further in Figure 7, cross-faults and normal faults extend for up to $5 \mathrm{~km}$ on both sides of the present zone of active transform movement, wifch was located in a 200-m-wide central zone. Hydrothermal activity (Fig. 8) was noted in this zone, as were numerous step faults with as much as $250 \mathrm{~m}$ of cumulative displacement.

Drflling at the mouth of the Gulf of California by the Deep Sea Drilling Profect (DSDP)

(Geot1mes, July 1979) resulted in a hypothesis about the opening of the Gulf that bears on interpretation of the structural geology in the vicinity of the Cerro Prieto field. The sequence began approximately $20 \mathrm{~m} \cdot \mathrm{y}$. ago wh the thered granite and alluvial outwash gravels. Perhaps by the la te Miocene ( 5 to $10 \mathrm{~m} \bullet \mathrm{y}$. ago) a rifting stage took place with listric faults (concave upward with a decrease dip angle at depth) in the basement. Around $4.5 \mathrm{~m} \cdot \mathrm{y}$. ago, subsidence wa active and the opening of the gulf began, wh th a transform-faultrelated opening of the present gulf around $3.5 \mathrm{~m} . \mathrm{y}$. (see also Terres and Crowell, 1979). To date, geophysical studies near Cerro Prieto have not revealed listric faults in the basement. However, rotational faults related to early rifting be

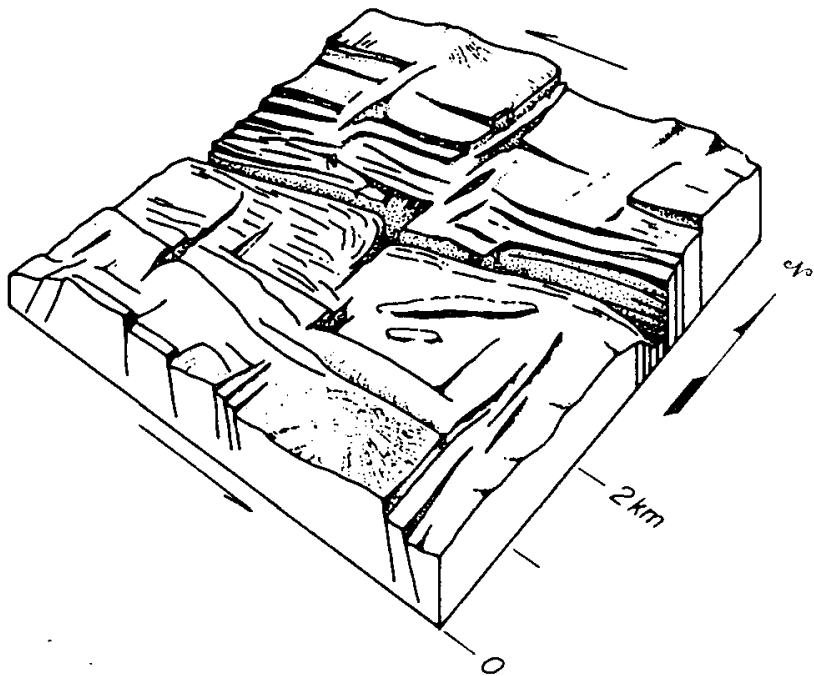

XBL $797-7583$

Figure 6. Interpretive block dlagram of a portion of the oceanic transform fault " $A$ " In the Famous a rea of the MidAtlant1c Ridge (after Choukroune et a1., 1978). The intersecting faults and 200 -m-wide active zone of strikeslip movement within a 4-km-wide trough suggest the possible complexity of faulting along the Cerro Prieto fault and within the production fleld.

Transform Foult " $A$ "

Famous Area Mid-Atlantic Ridge

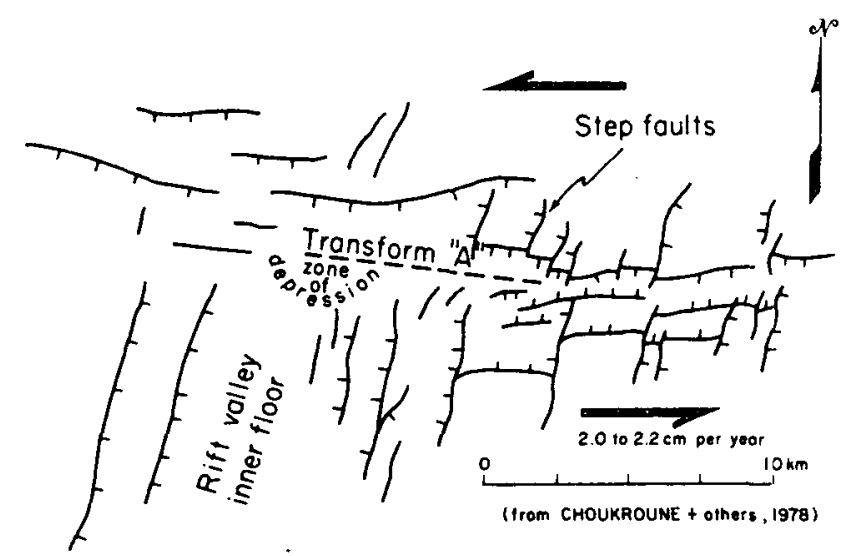

XBL $798-11490$

F1gure 7. Dlagram illustrating the complex faulting near an oceanic transform fault; a possible analog to Salton Trough faults. 


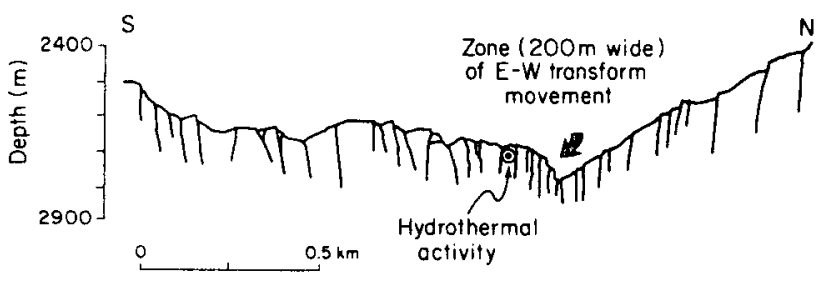

XBL $798-1149$

Figure 8. Section across the oceanic transform fault "A" based on deep-submersible dives showing active fulating within a wider fault zone.

confined to areas $50 \mathrm{~km}$ or more west and southwest of the geothermal field (see Gastil et al., 1979; Dokka and Merriam, 1979). It is important for a geological model of Cerro Prieto to include older basement faults that may couple with more recent strike-slip generated faults. Such coupling would increase the potential fluid flow network along fractures thus extending the area of maximum energy available for production.

Submersible studies in the Guaymas Basin in the central Gulf of California (Lonsdale and Lawor, 1980) are also interesting when considering the geology of the Cerro Prieto fleld. They show a transform fault that has a shear zone approximately $1 \mathrm{~km}$ wide. Cross-faul ts cover an area 1 to $2 \mathrm{~km}$ wide, and the seabed has hydrothermal minerals, which oxygen 1sotopes indicate precipita ted between $220^{\circ}$ and $240^{\circ} \mathrm{C}$.

Earlfer investigations in the Gulf of California by Sharman (1976) provide yet another 1mportant possible model (Fig. 9) for the zone between the Imperial and Cerro Prieto faults. As drilling progresses at Cerro Prieto reservolr modelers should consider that multiple basins separated by upraised blocks were formed sequent1a11y. Perhaps such an arrangement of basins represents episodic shifts of the heat source on a scale of 5 to $20 \mathrm{~km}$.

Another aspect of faulting related to spreading centers is indicated in Figure 10. The intersection angle between in fault and cross fault need not be $90^{\circ}$. Thus the geometry of the bisins east of the present Cerro Prieto fleld can have margins as much as $\pm 20^{\circ}$ from normal or parallel to the major regional fault.

Figure 11 represents one of many possible modes of evolution of oceanic transform faults and spreading centers. These "cartoons" are intriguing for they suggest patterns that may fit reglonal geophysics data. For example, the Tule Check geotherma 1 area $15 \mathrm{~km}$ northwest of Cerro Prleto could be an abandoned fracture zone, as seen in Figure 11 (D) with a remnant heat anomaly that is now cut off from the main Cerro Prieto and Imperlal pullapart system.

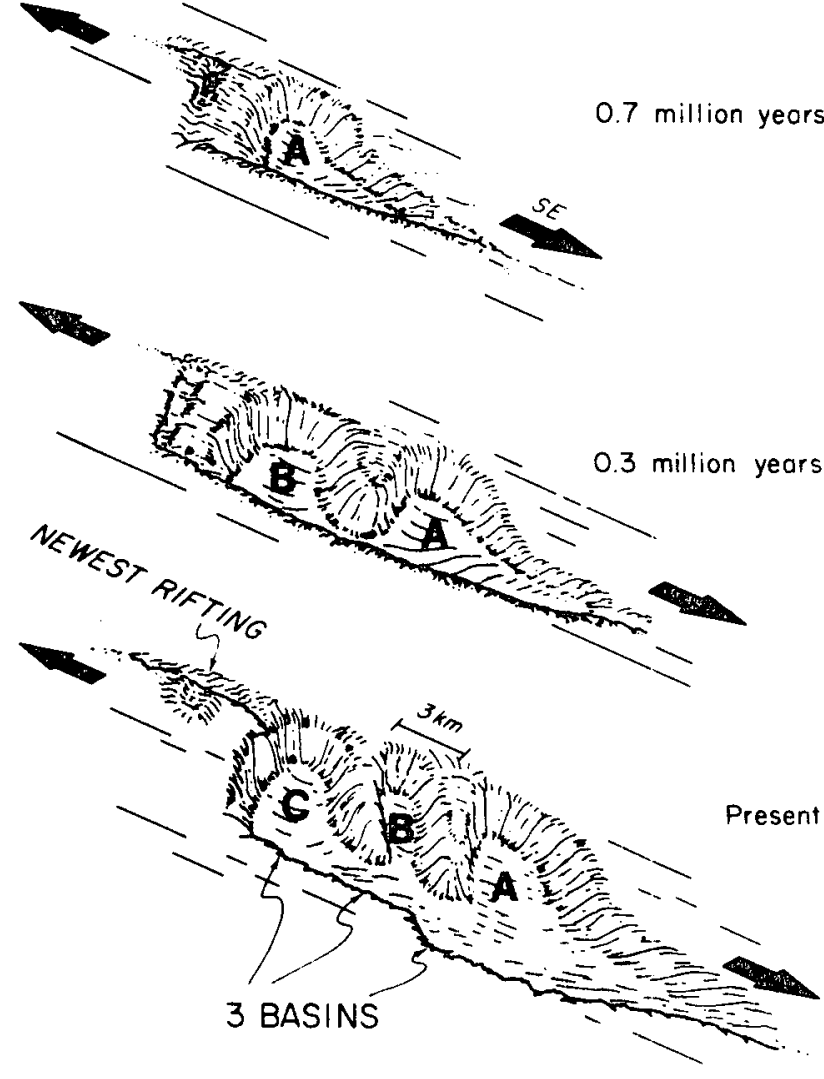

ofter SHARMAN, 1976

XBL $798-11489$

Figure 9. Interpretation of the evolution of the Carmen Basin in the Gulf of California; a possible analog to pull-apart basins in the Salton Trough. Note the assymetry and multiple-basin formation between two transform faults.

\section{EARTHQUAKE DATA}

A map of epfcenters and magnitudes for the Salton Trough (Fig. 12) indicates a high degree of tectonic activity. A story is shown by a reglonal plot of microseismic events (Fig. 13). Our interpretation of these events, most of 1 to 3 Richter magnitude, is that they are predominantly a serles of northeast-southwest cross-faults that link the Imperial and San Andreas faults. Over 800 events are plotted in Figure 14 with major concentrations at 4 to $6 \mathrm{~km}$ depth. The error on these depths could be as much as $\pm 2 \mathrm{~km}$, (G. Fuls, 1978, personal communication; see also Fuls et al., $1977 a, b, c, 1978 a, b, c)$.

The fact that depths of occurrence are shallow is important evidence of repeated activity that maintains fracturing and allows fluld flow through fractures at geothermal production depths in the 

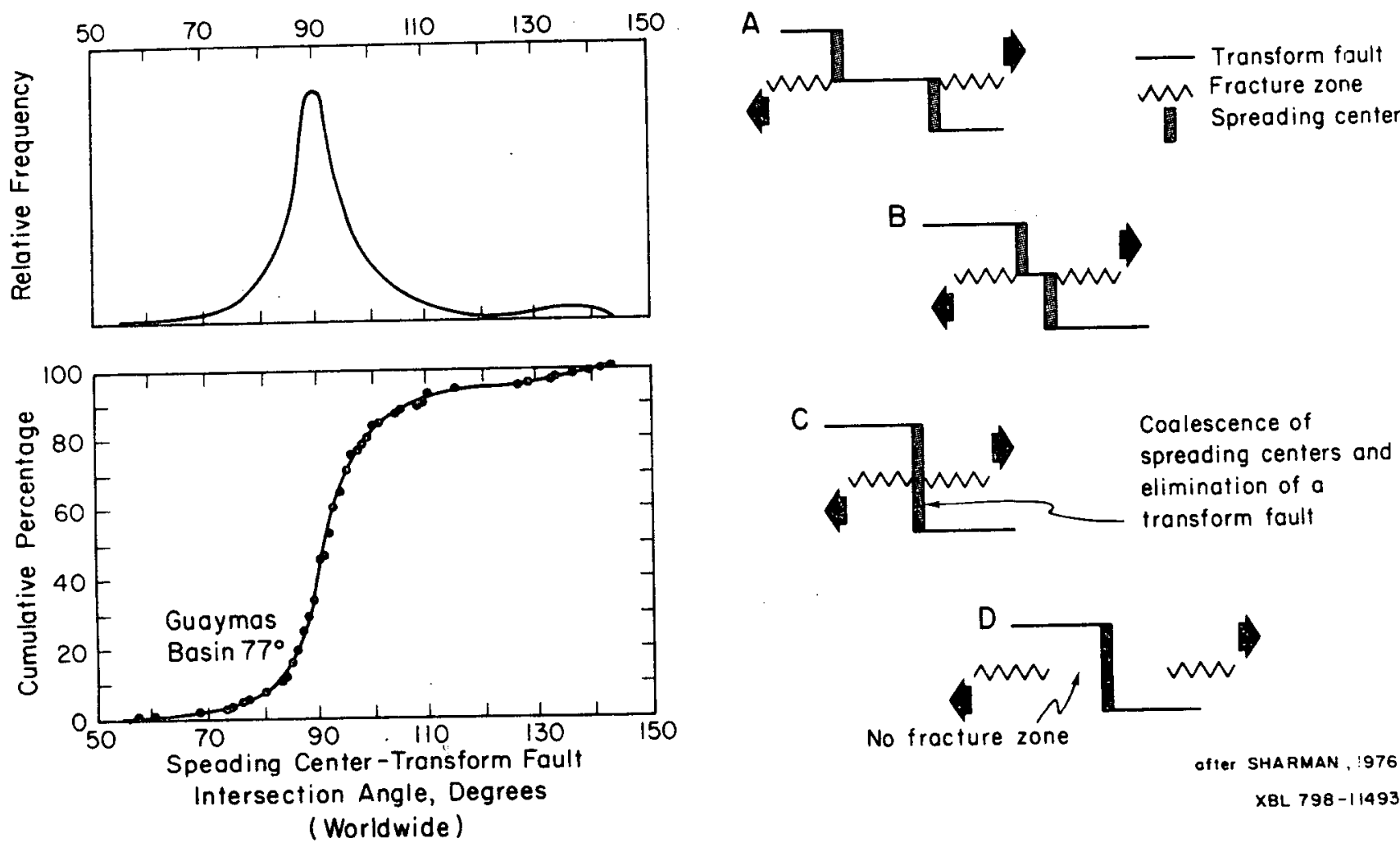

XBL $798-11494$

Figure 10. Confirmation of the concept that transform type faults need not be at $90^{\circ}$ to

form type faults need not be at 90 1976).

B

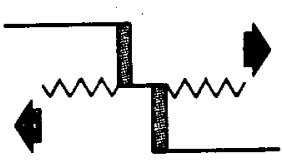

Figure 11. A cartoon of the possible evolution of the San Andreas, Imper 1al, and Cerro Prleto faults fllustrating where fracture zones should exist if these faults are pure transform types.

- Events $\geq 5,<6$ magnitude, $1932-1972$

6.5•1948 Events $>51912-1978$

Dato from Hileman, Allen and Nordquist, 1973 Johnson 1979
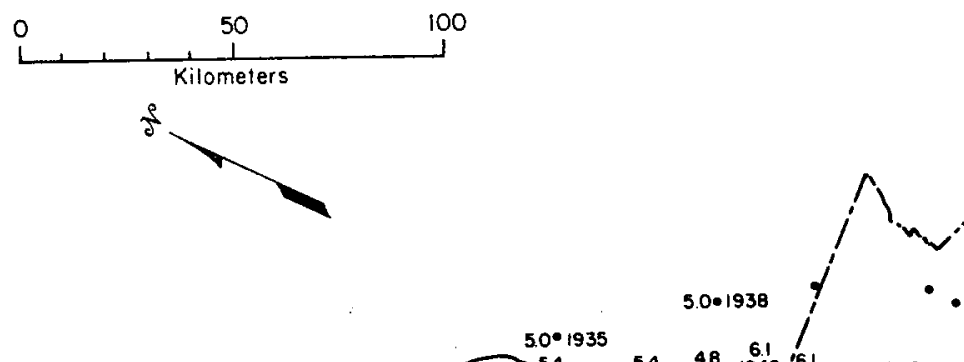

No fracture zone

ofter SHARMAN, 976

XBL $798-11493$

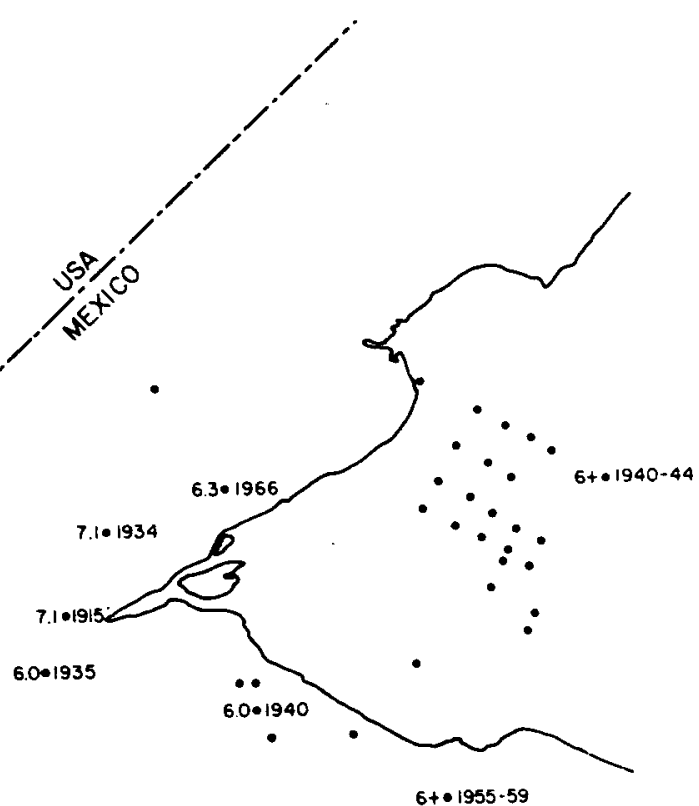

$X B L 797-7557 B$

Figure 12. Farthquake epicenters and recorded magnitudes in the Salton Trough for events of Richter magnitude 25 . 


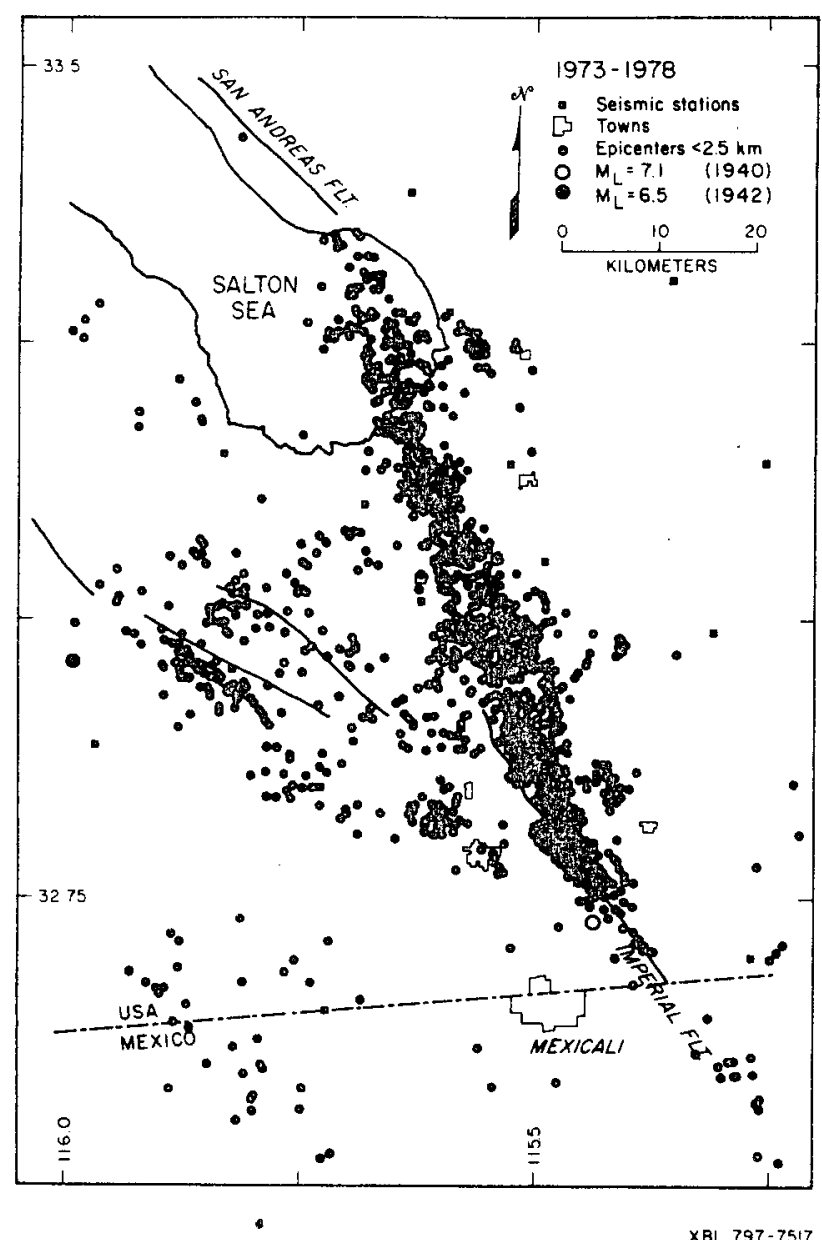

Figure 13. Central Salton Trough epicenters showing the connecting activity between the Imper $1 a 1$ and San Andreas faults (data from Johnson, 1979). Epicenter location error less than $2.5 \mathrm{~km}$. $M_{L}$ refers to local Richter magnitude.

Central Salton Trough

Earthquake Hypocenters

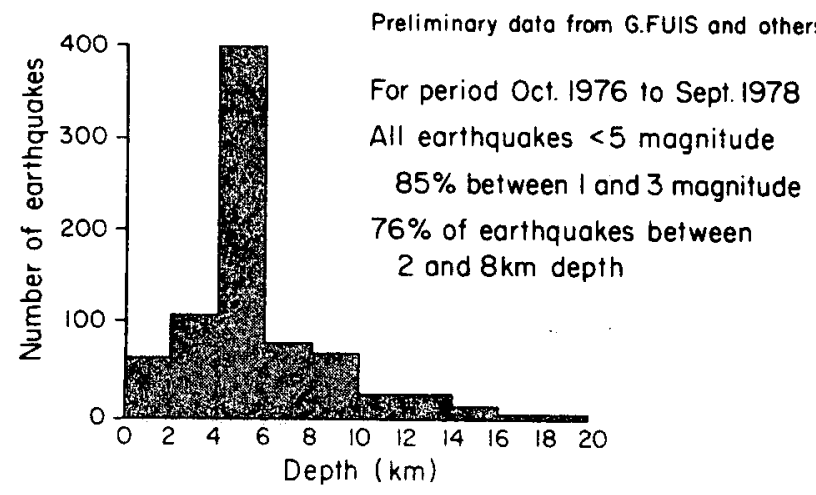

XBL $798-11492$
Salton Trough. More refined data on depths of earthquakes are needed for the Cerro Prieto area (F1g. 15) in order to document whether these events are in the production zone or at the interface of the deltaic sediment and the basement of granodiorite, volcanics, and metasedimentary rocks.

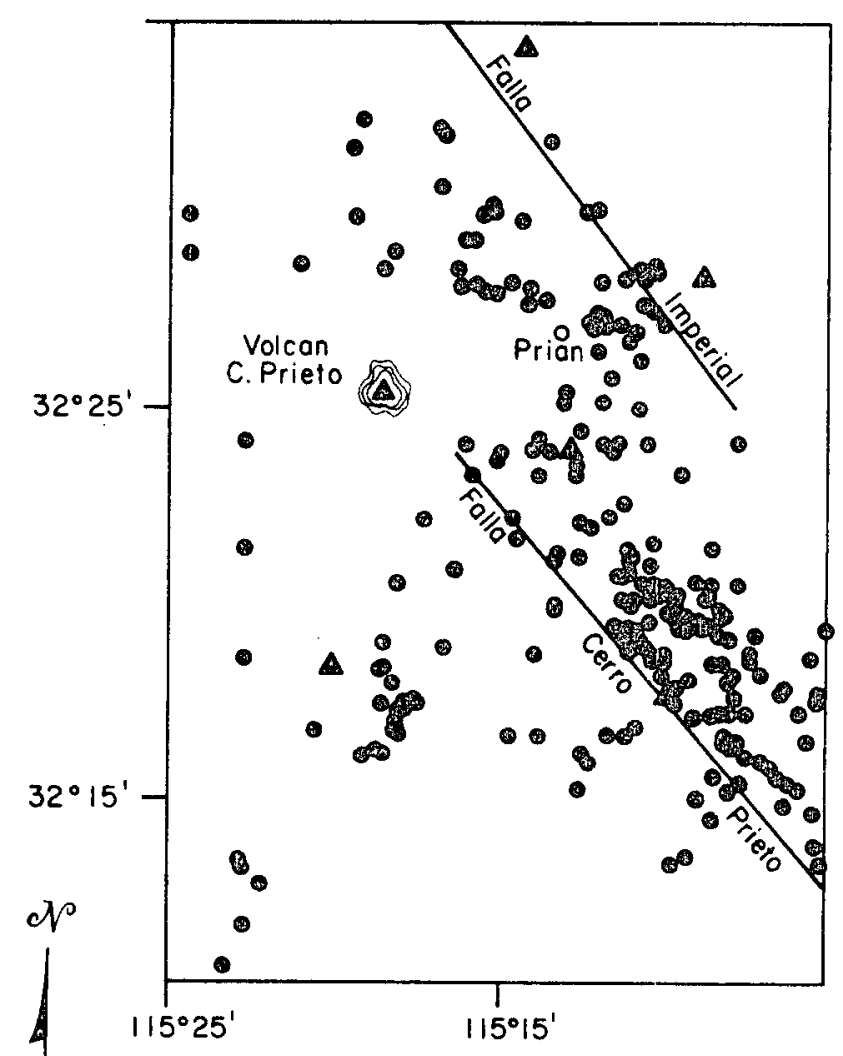

- Epicenters 1971-75 and 1977-78

$\Delta$ Seismic stotions

X日L. 797-7516

Figure 15. Earthquake epicenters in the vicinity of the Cerro Prieto and Imperial faults; data from Albores et al., 1979. Tectonic interpretations of recent movement between major en echelon faults are supported by these data and similar data along the north-trending zone between the Imperial and San Andreas faults.
Figure 14. Earthquake depths in the Salton Trough north of the Mexican-U.S. border, although difficult to quantify in the Salton Trough, show a concentration near geothermal fields in a zone from 2 to $6 \mathrm{~km}$. (Richter magnitudes, local). 
Scanning electron microphotographs of well cuttings and cores reveal mineral dissolution and mineral precipitation, clogging of pore throats, and apparent phases of overgrowth. Selected photographs present an idea of these features. A laminated siltstone in well NL-1 at $1888 \mathrm{~m}$ (Fig. 17) shows little porosity and 11ttle densffication, while deeper samples in NL-1 at $2720 \mathrm{~m}$ in the production region (Ftgures $18,19,20)$ 11lustrate clogging and precipitation. Figures 21 and 22 at $3209 \mathrm{~m}$ in the same we 11 document a dramatic change to a metamorphosed zone with reduced secondary porosity. Well $\mathrm{M}-38$ samples at 1215 to $1372 \mathrm{~m}$ show clay and framework minerals (FIgs. 23 and 24) and $M-3$ at $2203 \mathrm{~m}$ (F1g. 25) Is a spectacular example of silica mineral precipitation adjacent to clay.minerals.

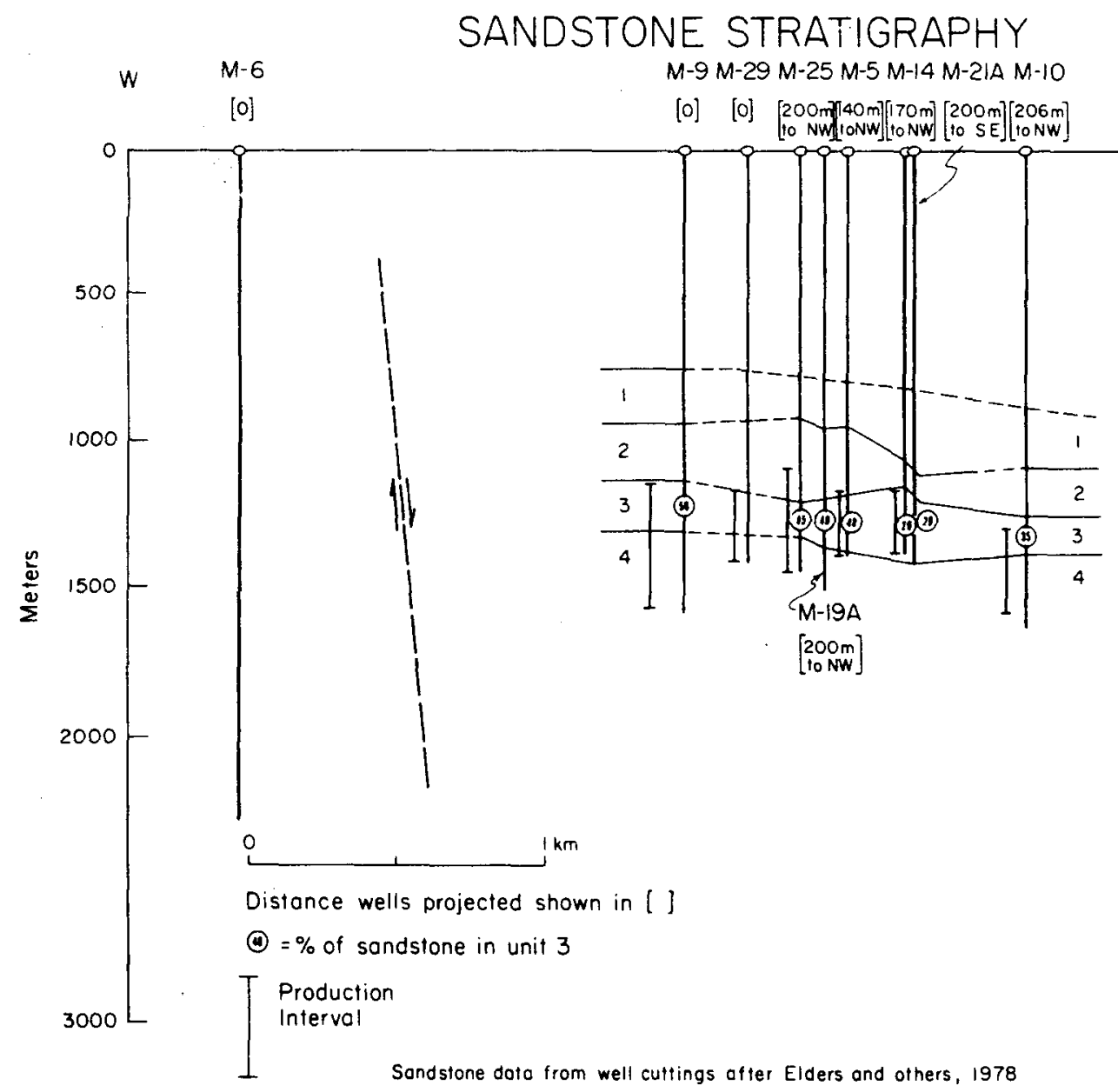

M-53

[0]

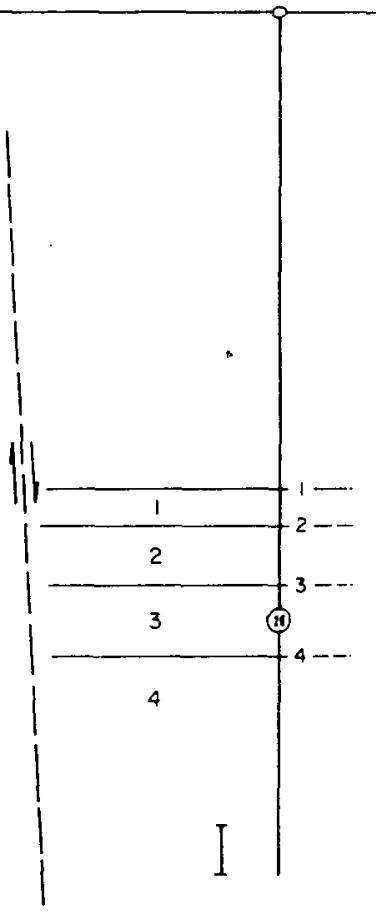

Figure 16. Sandstone units defined by relatively continuous major shale zones. Within the production reservolr the sandstone percentage, as in un1t 3, varies from $20 \%$ to $50 \%$ with a minimum near well M-14 (see Fig. 5 for well locations). 


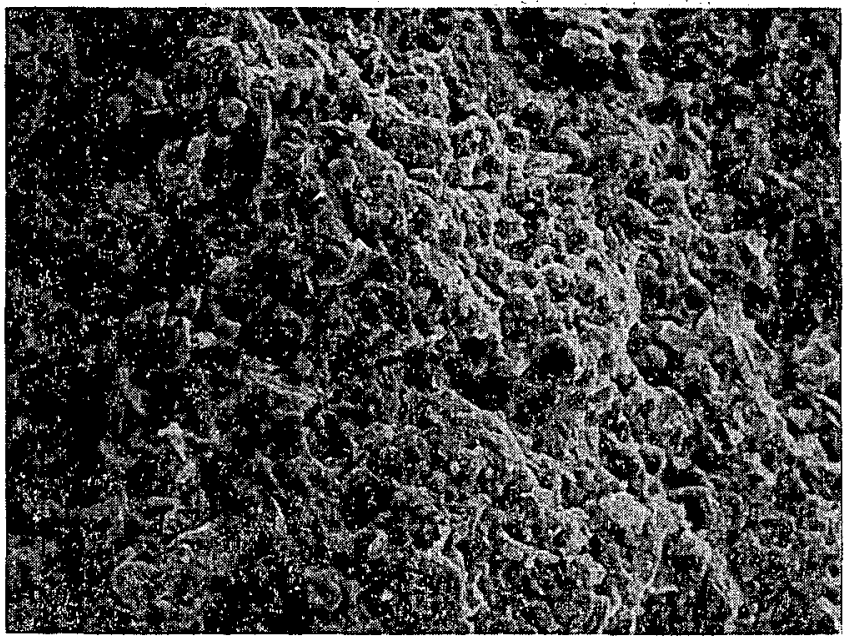

XBB 799-12528

Figure 17. Low-porosity laminated deltaic siltstone from well NL-1 at $1888 \mathrm{~m}$ depth; field of view across the SEM photograph is $0.2 \mathrm{~mm}$.

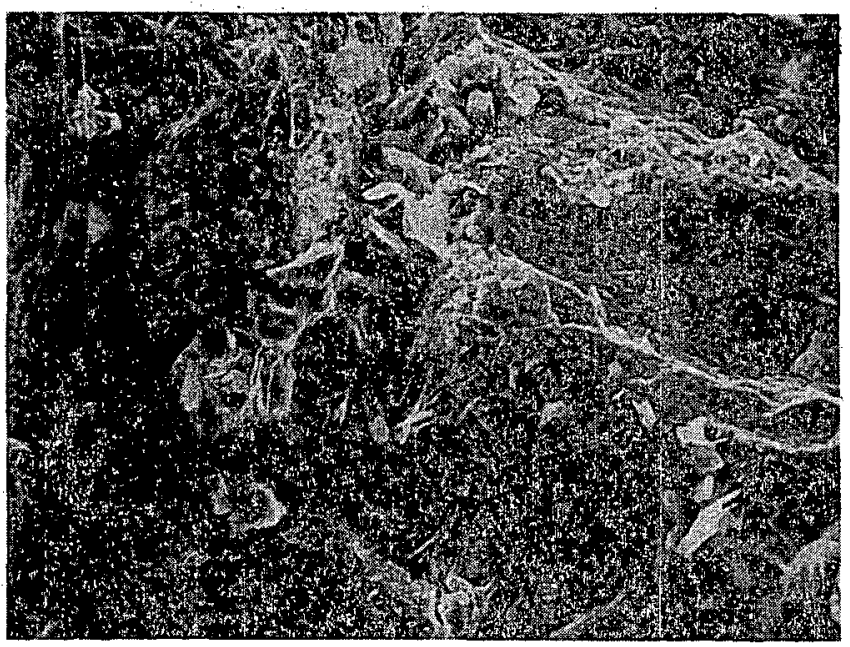

XBB 799-12511

Figure 19. Sandstone; closeup of the same sample as Figure 18. Note the long hairlike crystals (1llite?) and wafer-shaped clay or zeolite minerals partially filling a pore throat between sand grains. Sample taken at $2720 \mathrm{~m}$ depth from we11 NL-1. Field of view across the photograph is $0.2 \mathrm{~mm}$. This is an example of altered secondary permeability effects.

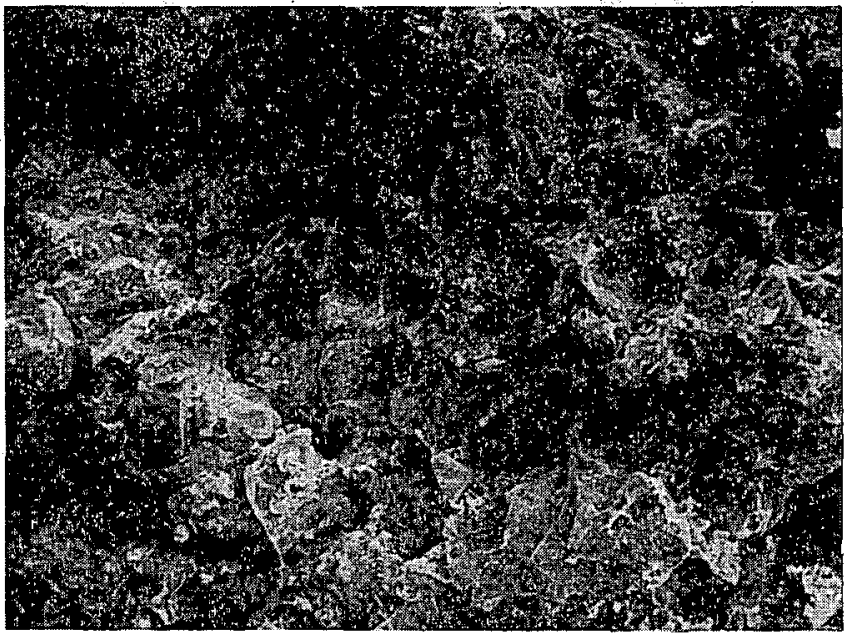

XBB 799-12516

Figure 18. Sandstone showing mixed secondary porosity and newly precipitated hydrothermal minerals from production zone of well NL-1 at $2720 \mathrm{~m}$ depth. Field of view across the SEM photograph is $0.2 \mathrm{~mm}$.

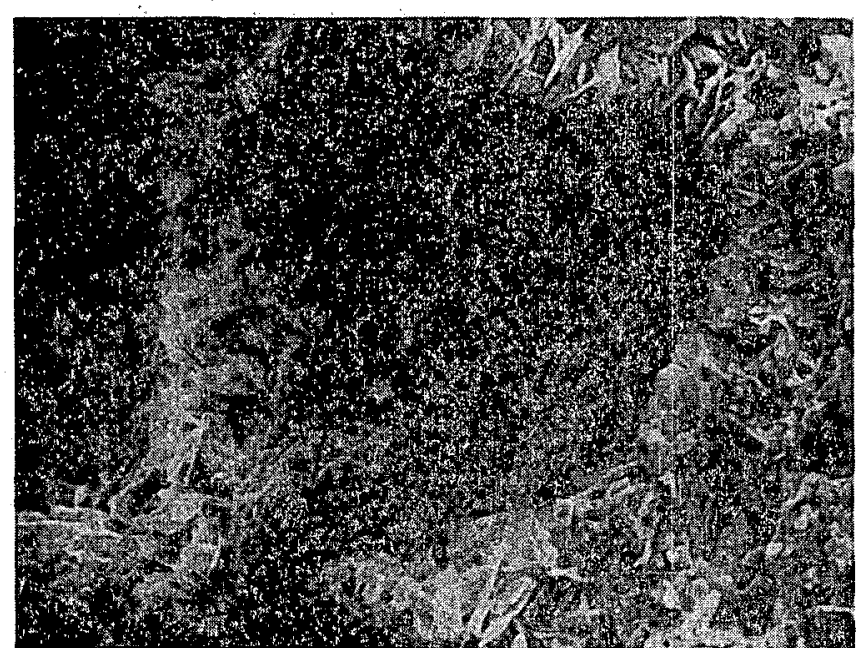

XBB 799- 12518

Figure 20. Sandstone; closeup view of a portion of Figure 18. During sample preparation a grain was plucked leaving behind the hydrothermally precipitated clay cement. Sample from $2720 \mathrm{~m}$ depth in well NL-1. Field of view across the SEM photograph is $0.2 \mathrm{~mm}$. 


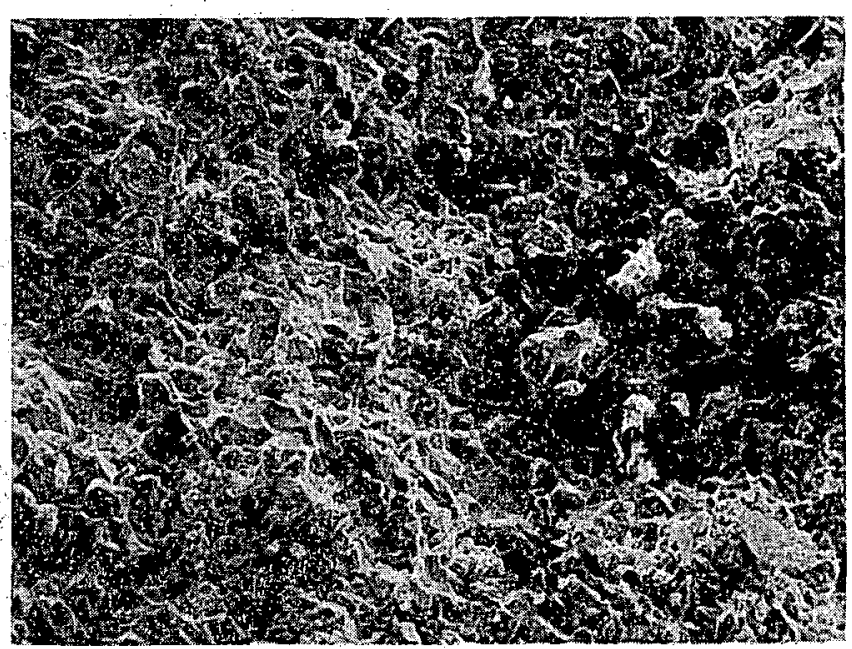

XBB 799-12524

Figure 21. Metamorphosed very dense sandstone from well NL-1 at $3209 \mathrm{~m}$ depth. Field of view is $1.0 \mathrm{~mm}$. This is an example of a super-mature secondary porosity zone susceptible to microfracturing.

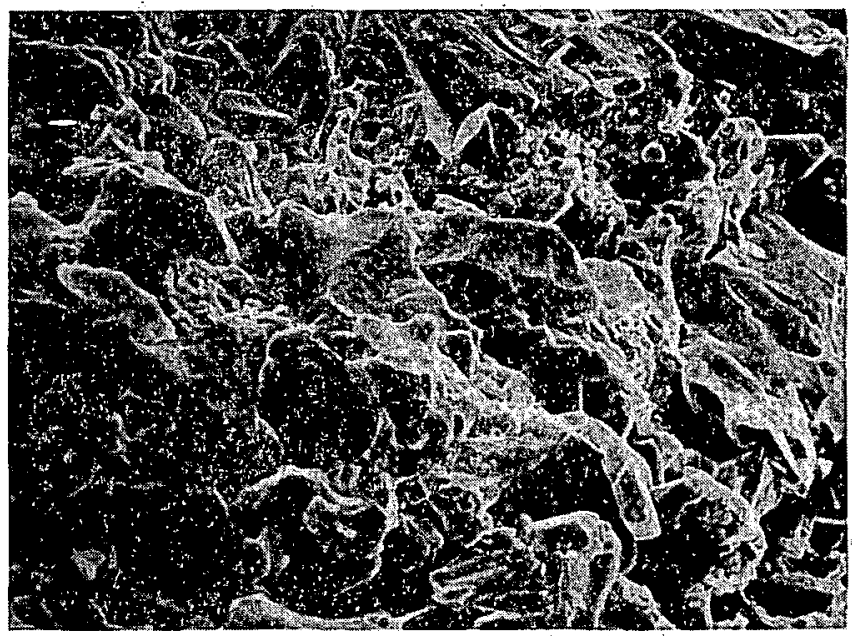

XBB 799-12527

Figure 22. Closeup of Figure 21 showing reduced porosity due to precipitation of framework minerals. Note how grains were broken durng sample preparation compared with Figure 18. Sample from well NL-1 at 3209 m depth. Field of view across the SEM photograph is $0.5 \mathrm{~mm}$.

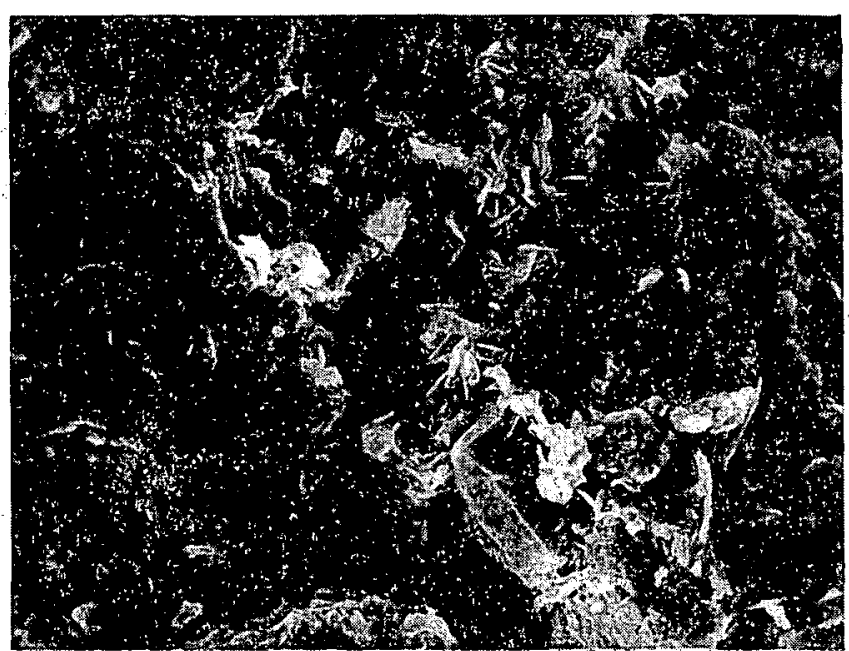

XBB $797-9450$

Figure 23. Clay and framework minerals, or mineral overgrowth in a pore space. Sample taken from well $\mathrm{M}-38$, at depths from 1215 to $1372 \mathrm{~m}$; fleld of view across the SEM photograph is $0.1 \mathrm{~mm}$.

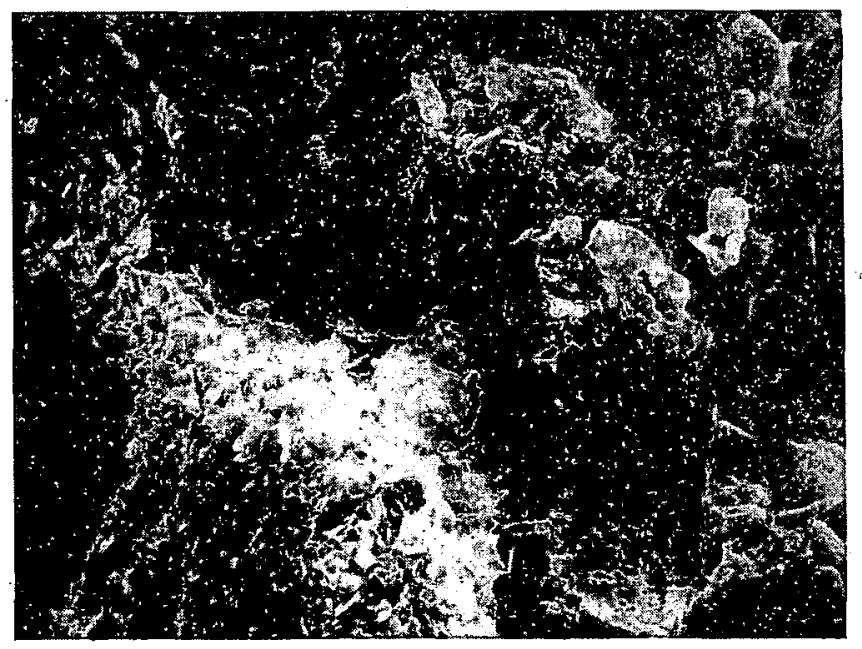

$\mathrm{XBB} \quad 797-9451$

Figure 24. Leaching of a crystal face and a massive clay mineral agregate. Samples taken from well M-38 at $1215 \mathrm{~m}$ depth. Field of view in the SEM image is $1.0 \mathrm{~mm}$. 


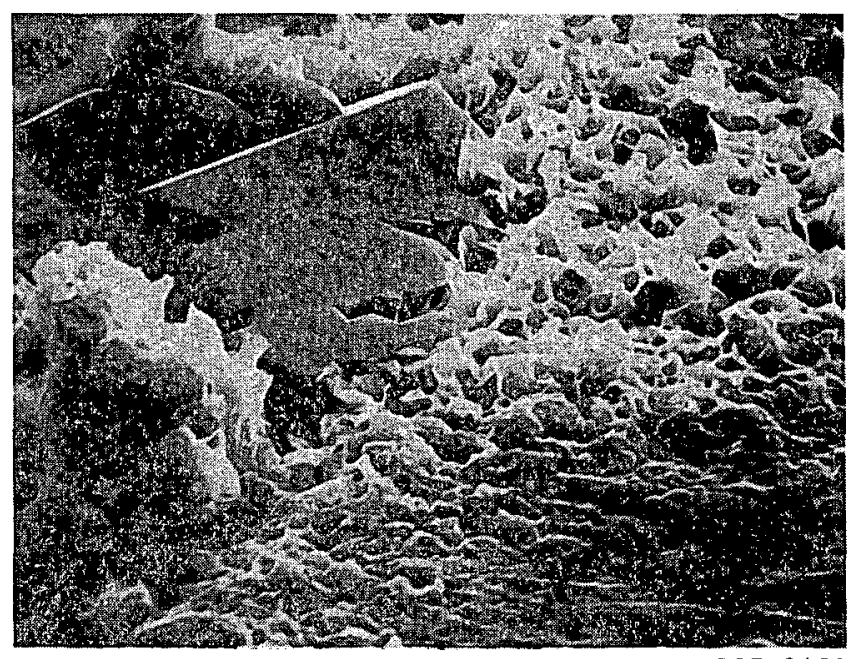

XBB 797-9459

Figure 25. Nearly pure silicate minerals (EDAX scan shows only S1) adjacent to honeycomb clays ( $\mathrm{Fe}, \mathrm{Mg}$, Al rich) overgrowths. Both features greatly reduce permeability. Sample from well $\mathrm{M}-3$, at $2203 \mathrm{~m}$ depth. Field of view across the SEM photograph is $0.05 \mathrm{~mm}$.

\section{ACKNOWLEDGMENT}

Work performed for the U.S. Department of Energy, Division of Geothermal Energy, under contract $W-7405-E N G-48$.

\section{REFERENCES CITED}

Albores L., A., Reyes Z., C. A., Brune, J. N., González G., J., Garcilazo M., L., and Suárez V., F., 1979, Seismicity studies in the region of the Cerro Prieto geothermal field, in Proceedings, First Symposium on the Cerro Prieto Geothermal Field, Baja California, Mexico, September 1978: Berkeley, Lawrence Berkeley Laboratory, LBL-7098, p. 227-238.

Alonso E., H., 1966, La zona geotérmica de Cerro Prieto, Baja California: Soc. Geol. Mexican Bol., v. 29, p. 17-47.

Alonso E., H., Dominguez A., B., Lippmann, M. J., Mañon M., A., Schroeder, R. C., and Witherspoon, P.A., 1979, Recent activities at the Cerro Prieto field, In Kruger, P., and Ramey, H. J., Jr., eds., Proceedings, Fourth Workshop, Geothermal Reservoir Engineering, December 1978: Stanford, Stanford University p. 5-14.

Babcock, E., 1974, Geology of the northeast margins of the Salton Trough, Salton Sea, California: Geological Society America Bulletin, v. 85, p. $321-332$.

Barnard, F., 1968, Structural geology of the Sierra de los Cucapas, northeastern Baja California (Ph.D. dissertation): Denver, University of Colorado, $155 \mathrm{p}$.
Biehler, S., Kovach, R., and Allen, C. R., 1964, Geophysical framework of northern end of the Gulf of California structural province, In van Ande1, T. H., and Shor, G. G., ed., Marine geology of the Gulf of California: Amer. Assoc. Petroleum Geol., Memoir 3, p. 126-143.

Chan, T. and Tewhey, J. D., 1977, Subsurface structure of the southern portion of the Salton Sea geothermal field: Livermore, Lawrence Livermore Laboratory, UCRL-52354, $13 \mathrm{p}$.

Choukroune, P., Francheteau, J., and Le Pichon, X., 1978, In situ structural observations along Transform fault $A$ in the FAMOUS area, Mid-Atlantic Ridge; Geological Society America Bulletin, v. 89, p. 1013-1029.

Corwin, R. F., Diaz C., S.,. and Rodriguez B., J., 1978, Self-potential survey at the Cerro Prieto goethermal field, Baja California, Mexico: Berkeley, Lawrence Berkeley Laboratory, LBL-7065.

Crowe, B. M., 1978, Cenozolc volcanic geology and probable age of inception of basin-range faulting in the southeasternmost Chocolate Mountains, California: Geological Soclety America Bulletin, v. 89, p. 251-264.

de Boer, J., 1980, Paleomagnet1sm of the Quaternary Cerro Prieto, Crater Elegante, and Salton Buttes volcanic domes in the northern part of the Gulf of California rhombochasm: Berkeley, Lawrence Berkeley Laboratory, LBL-9742.

Deep Sea Drilling Project, 1979, Leg 64 seeks evidence on development of basins in the Gulf of California: Geotimes, v. , no. p. 18-20.

De la Fuente, M., and Sumner, J., 1974, Estudio aeromagnetico del Delta del Rio Colorado, Baja California, México; Geofisica Internactona1, v. 14, p. 35-48.

Delaney, P., and Pollard, D. D., 1980, Deformation of host rocks and flow of magma during growth of minette dikes and breccia bearing intrusions near Shyrock, New Mexico. U.S. Geol. Survey prof. paper (in press).

Dokka, R. K., and Merriam, R. H., 1979, Tectonic evolution of the main gulf escarpment between latitude $31^{\circ} \mathrm{N}$ and $30^{\circ} \mathrm{N}$, northeastern Baja California, Mexico, in Abbott, R. L., and Gastil, R. G., eds., Baja California Geology: San Diego, San Diego State University, p. 139-147.

Donnelly, M. F., 1974, Geology of the Sierra del Pinacate volcanic field, northern Sonora, Mexico, and southern Artzona, U.S. (Ph.D. dissertation): Stanford, Stanford University, 722 p.

Elders, W. A., Hoagland, J. R., Olson, E. R., Mc Dowe11, S. D., and Collier, P., 1978, A comprehensive study of samples from geothermal reservoirs: Petrology and 11ght stable 1sotope geochemistry of twenty-three wells in the Cerro Prieto geothermal field, Baja California, Mexico: Riverside, California, Institute of Geophysics and Planetary Physics, University of California, Report UCR/IGPP$78 / 26$, p. 263 .

Fuis, G., and others, $1977 \mathrm{a}$, Prel1minary ca ta logues of earthquakes in the northern Imperial Valley, Calffornia: U.S. Geological Survey Open-File Report, 77-694. , $1977 \mathrm{~b}$, Preliminary catalogues of earthquakes in the northern Imperial Valley, 
California: U.S. Geological Survey Open-File Report, 77-869.

, 1977c, Preliminary catalogues of earthquakes in the northern Imperial Valley, California: U.S. Geological Survey Open-File Report, 77-431.

, 1978a, Preliminary catalogues of earthquakes in the northern Imperial Valley, California: U.S. Geological Survey Open-File Report, 78-74.

, 1978b, Preliminary catalogues of earthquakes in the northern Imperial valley, California: U. S. Geological Survey Open-File Report, 78-671.

, 1978c, Preliminary catalogues of earthquakes in the northern Imperial valley, California: U. S. Geological Survey Open-File Report, 78-673.

Cast11, G., and Krummenacher, .., 1977, Reconnatssance geology of coastal Sonora between Puerto Lobos and Bahta Kino: Geological Society America Bulletin v. 88, p. 189-198.

Gastil, R. G., Phillips, R. P., and Allison, E. C., 1975, Reconnaissance geology of the State of Baja California: Geological Society America Memo1r 140, 170 p.

Goulty, N. R., and Golman, R., 1978, Repea ted creep evants on San Andreas Fault near Parkfield, Calffornia, recorded by a Strainmeter array: Journal Geophys1cal Research, v. 83, p. 5415-5419.

Henyey, T., and Bischoff, J., 1973, Tectonic elements of the northern part of the Gulf of Calffornia: Geological Society America Bulletin, v. 84, p. 315-330.

Hileman, J. A., Allen, C. R., and Nordquist, J. M., 1973, Selsmicity of the southern Californta region 1932 to 1972: Pasadena, Seismological La boratory, Californta Institute Technology, $94 \mathrm{p}$.

Howard, J., et a1., 1979, Geothermal resource and reservoir investigations of U. S. Bureau of Reclamation leaseholds at East Mesa, Imperial Valley, California: Berkeley, Lawrence Berkeley La bora tory, LBL-7094; 305p.

Johnson, C. E., 1979, I, CEDAR an approach to the computer automation of short-period local selsmic networks; II, Selsmotectonics of the Imperial Valley of Southern Californta (Ph.D. dissertation): Pasadena, Calif. Inst. Technology, $332 \mathrm{p}$.

Johnson, C. E. and Hadley, D. M., 1976, Tectonic implications of the Brawley earthquake swarm, Imperial Valley, January, 1975; Bulletin Selsmological Society America, v. 66, p. 1133-1144.

Rasameyer, P., 1976, Preliminary interpretation of resistivity and seismic refraction data from the Salton Sea geothermal field: Livermore, Lawrence Livermore La boratory, UCRL$52115,10 \mathrm{p}$.

Ka sameyer, P., Younker, L., and Tewhey, J., 1978, Salton Sea geothermal system: II, Therma I source modeling and resource assessment: Livermore, Lawrence Livermore Laboratory, $30 \mathrm{p.}$, unpub. report.
Lofgren, B. E., 1979, Measured crustal deformation in Imperial Valley, Callfornta, in Proceedings, First Symposium on Cerro Prieto Geothermal Field, Baja Californta, Mexico, Septenber 1978: Berkeley, Lawrence Berkeley Laboratory, LBL-7098, p. 141-145.

Lonsdale, P., and Lawer, L. A., 1980, Submersible study of immature plate boundary zones in the Gulf of California: Geological Soclety America Bulletin, 8 p. (in press)

Mañon M., A., Mazor, E., Jiménez S., M. E., Sáncheż., A., Faus to L., J. J., and Zenizo, C., 1977, Extensive geochemical studies in the geothermal field of Cerro Prieto, Mexico: Berkeley, Lawrence Berkeley La boratory, $L B L-7019,113 \mathrm{p}$.

Meidav, T., and Howard, J. H., 1979, An update of tectonics and geothermal resource magnitude of the Salton Sea geothermal resource: Geothermal Resources Council Transactions, v. 3, p. 445-448.

Mefdav, T., and Rex, R., 1970, Investigation of geothermal resource in the Imperial Va1ley: Riverside, Californta, Institute Geophysics and Planetary Physics, University of California, $54 \mathrm{p}$.

Meldav, T., et al., 1976, An electrical resistivity survey of the Salton Sea geothermal field, Imperial Valley, California; Livermore, Lawrence Livermore La bora tory, UCR.L-13690, v. 1 and $2,68 \mathrm{p}$.

Mercado G., S., 1976, Movement of geothermal fluid and temperature distribution in the Cerro Prieto geothermal field, Baja California, Mexico, in Proceedings Second United Nations Symposium on the Development and Use of Geotherma 1 Resources, San Francisco, May 1975: Vashington, D. C., U. S. Government Printing office, v. 1, p. 492-494.

Noble, J. E., Mañon M., A., Lippmann, M. J., and Witherspoon, P. A., 1977, A study of the structural control of fluid flow within the Cerro Prieto geothermal field, Baja California, Mexico: Dallas, Society of Petroleum Engineers, SPE-6763.

Ortlieb, L., 1978, Neotectonics from rine terraces along the Gulf of California, 1n Proceedings Symposium on Earth Rheology and La te Isostat1c Movements, Stockholm, 1977: New York, John Wiley and Sons.

Phlilips, R. P., 1964, Selsmic refraction studies In the Gulf of California, in van Andel, T. H., and Shor, G. G., eds., Marine geology of the Gulf of Callfornia: Amer. Assoc. Petrol. Geol., Memo1r 3, p. 90-121.

Prian C., R., 1979, Lithologic conditions of the Cerro Prieto wells based on well interpre.. tations; in Proceedings, First Symposium on the Cerro Prieto Geothermal Field, Baja California, Mexico, September 1978: Berkeley, Lawrence Berkeley La bora tory, LBL-7098, p. 49-56.

Proctor, R. J., 1968, Geology of the Desert Hot Springs/Upper Coachella Valley area, Calffornia: San Francisco, California Division of Mines and Geology, Special Report, $50 \mathrm{p}$. 
Puente C., I., and de la Peña L., A., 1979, Geologia del campo geotérmico de Cerro Prieto, in Proceedings, First Symposium on the Cerro Prieto geothermal field, Baja Californta, Mexico, September 1978: Berkeley, Lawrence Berkeley La boratory LBL-7098; p. $17-40$.

Razo, A., 1976, Sinopsis geológica del campo geotérmico de Cerro Prieto, Baja California: Mexical1, Comision Federal de Electricidad. Internal report.

Reed, M. J., 1976, Geology and hyd rotherma 1 metamorphism in the Cerro Prieto geothermal fleld, Mexico, in Proceedings, Second United Nations Symposium on the Development and Use of Geothermal Resources, San Francisco, May 1975: Washington, D. C., U. S. Government Printing office, v. 1, p. 539-547.

Sharman, G., 1976, The plate tectonic evolution of the Gulf of California (Ph.D. dissertation): San Diego, Untversity of California, $86 \mathrm{p}$.

Sharp, R. V., 1976, Surface faulting in the Imperial Valley during the earthquake swarm of January-Fe bruary, 1975: Bulletin Seismological Soclety of America, v. 66, p. 1145-1154.

Soto-Ptneda, S., 1975, Campo geotérmico de Cerro Prieto sobre la falla San Jacinto y su posible ampliación hacia la falla Imperial. Comisión Federal de Electricidad, Mexico, Internal Report, June, $13 \mathrm{p}$.

Sumner, J. R., 1972, Tectonic significance of gravity and aeromagnetic Investigations at the head of the Gulf of California: Geological Soclety of America Bulletin, v. 83, p. 31033120.

Sylvester, A. G., and Smith, R. R., 1976, Tectonic transpersion and bement-controlled deformation in San Andreas fault zone, Salton Trough, California: American Association of Petroleum Geolog1sts Bulletin, v. 60, p. 2081-2101.

Terres, R., and Crowell, J. C., 1979, Pla te tectonic framework of the San Andreas/Salton Trough functure, in Tectonics of the juncture between the San Andreas fault system and the Salton Trough, southeastern California: San Mego, University of California, p. 15-26.
Tewhey, J. D., 1977, Geolog1c characteristics of a portion of the Salton Sea geothermal field; Livermore, Lawrence Livermore Laboratory, UCRL-52267, $51 \mathrm{p}$.

Todd, V. R., and Hoggatt, W. C., 1976, Elsinore fault zone in the Tierra Blanca Mountains, Fastern San Diego Log California (abstract): Geological Soctety of America, Program and Abstracts, p. 416-417.

Truesde11, A. H., 1979, The use of fluld geochemistry to indicate reservoir processes at Cerro Prieto, Mexico, in Kruger, P., and Ramey, H. J., Jr., eds., Proceeding.s, Four th Workshop, geothermal reservolr eng ineering, Stanford, December, 1978: Stanford, Stanford University, p. 239-242.

U.S. Geolog1cal Survey, 1972, The Borrego Mountain earthquake of April 9, 1968: U. S. Geological Survey Professional Paper 787, 207 p.

Valette, J. N., and Esquer P., I., 1979, Geochemistry of superficial emissions in the Cerro Prieto Geothermal Field (abstract), in Program and Abstracts, Second Symposium on the Cerro Prieto Geothermal Field, Baja California, Mexico, October 17-19: Mexicali, Comisión Federal de Electricidad, p. 32-33.

Vonder Haar, S. P. and Gorsline, D. S., 1975 , Flooding frequency of hypersaline coastal environments using orbital imagery--geologic implications; Sclence, v. 190, p. 147-149. , 1977, Hypersaline lagoon deposits and processes in Baja California, Mexico: in Geoscience and Man, v. 17, p. 165-177. , 1979; Flooding frequency and sedimentation unit correlation of tidal flat and coastal saline facies along the upper Gulf of California, Mexico: Geological Society America Abstracts with Programs, Annual Mtg., November 1979 , p. 533.

Vonder Haar, S., and Puente C., I., 1979, Fault intersections and hybrid transform faults in the southern Salton Trough geothermal area, Baja California, Mexico: Geothermal Resources Counc1l Transactions, v. 3, p. 761-764. 
This report was done with support from the Department of Energy. Any conclusions or opinions expressed in this report represent solely those of the author(s) and not necessarily those of The Regents of the University of California, the Lawrence Berkeley Laboratory or the Department of Energy.

Reference to a company or product name does not imply approval or recommendation of the product by the University of California or the U.S. Department of Energy to the exclusion of others that may be suitable. 
LAWRENCE BERKELEY LABORATORY

UNIVERSITY OF CALIFORNIA

BERKELEY, CALIFORNIA 94720 